\title{
The effect of amodiaquine on oestrus cycle, ovarian histology and oxidative stress makers in regular cyclic sprague-dawley rats
}

\author{
Gbotolorun, S.C., Osinubi, A.A.A., Oremosu, A.A and Noronha, C.C. \\ Department of Anatomy, Faculty of Basic Medical Sciences, College of Medicine, \\ University of Lagos, Nigeria.
}

\begin{abstract}
This study investigated the effect of Amodiaquine hydrochloride (AQ.HCl) administered by gavage on the oestrous cycle, ovarian morphology and on the antioxidant status of superoxide dismutase (SOD) and catalase (CAT) in the ovary of 15 regular cyclic Sprague-Dawley rats. The experiment was divided into 3 groups as follows: group l- received $6 \mathrm{mg} / \mathrm{kg}$ bw AQ. $\mathrm{HCl}$ for 28 day; group II- received $12 \mathrm{mg} / \mathrm{kg}$ bw of AQ. $\mathrm{HCl}$ for 28 days; and group III- received distilled water and served as control. The animals were autopsied on the $28^{\text {th }}$ day by cervical dislocation. Result showed that the mean length of the oestrous cycle was prolonged in all the AQ. $\mathrm{HCl}$ treated rats when compared to the control. The increase in mean cycle length was statistically significant $(p<$ 0.05 ) in the group that received $12 \mathrm{mg} / \mathrm{kg}$ bw of $\mathrm{AQ} . \mathrm{HCl}$. Histological sections of the ovaries of the rats treated with $\mathrm{AQ} . \mathrm{HCl}$ revealed that the most remarkable change was widespread follicular atresia when compared to the control. The study revealed a reduction in the antioxidant status of SOD and CAT in the ovary. This reduction in anti-oxidant status was statistically significant $(p<$ 0.05) for CAT. The result of this study showed that AQ. $\mathrm{HCl}$ is deleterious to the ovary by prolonging the length of the oestrous cycle, producing widespread follicular atresia and depletion of the enzymatic antioxidant status of SOD and CAT and consequently resulting in a state of oxidative stress in the ovary.
\end{abstract}

Keywords: Amodiaquine, oestrous cycle, follicular atresia, anti-oxidants

\section{INTRODUCTION}

Amodiaquine $(\mathrm{AQ})$ belongs to a class of drugs known as the 4-aminoquinoline compounds. The synthesis of this drug was first reported at the meeting of the American Chemical Society in 1946 and is in wide use mainly as an antimalarial drug (Neftel et al., 1986; Misra et al., 1995; Olliaro and Taylor, 2004). In Africa, $A Q$ is significantly more effective than chloroquine in parasite clearance, and a faster clinical recovery (Olliaro and Taylor, 2004; Schellenberg and Menendez). It is also more effective even in areas of high chloroquine resistance (Olliaro et al., 1996; Brasseur et al., 1999). Following reports of serious adverse effects (Neftel et al., 1986; Markham et al., 2007) associated with the use of $A Q$ as a chemoprophylaxis, the use of this drug declined abruptly in 1986 and was eventually removed from the Essential Drug List in 1990 (Anon, 1990). Subsequent re-evaluation led to appreciation that the risk of toxicity associated with short-term $A Q$ treatment appeared to be lower than that associated with $A Q$ chemoprophylaxis (Olliaro et al., 1996). AQ is now making a come-back and is now in the spotlight as a partner drug in the World Health
Organization (WHO) recommended Artemisinin Based Combination Therapies (WHO, 2001). In malaria-endemic parts of the World, the frequency of malaria attacks can be several in a year and self medication with antimalarial drugs is common (Perret and Ngomo 1993; Minzi et al., 2003). In countries where $A Q$ is the first-line drug whether alone as a single regimen or in combinations, the issue of toxicity with repeated treatments following several malaria attacks may arise.

$A Q$ is also used in the treatment of chronic disorders such as lupus erythematosus, rheumatoid arthritis and lepra reactions (Bepler et al.,1959; Pomeroy et al., 1959). A number of investigators have attempted to study the effect of $A Q$ on pregnancy and pregnancy outcomes (Steketee et al., 1987; Kone et al., 2002; Thomas et al., 2004).

However, there remains a dearth of literature on the long-term effect of $A Q$ administration on the histology and enzymatic anti-oxidant activities of CAT and SOD in the ovary of the non-pregnant female. 


\section{MATERIALS AND METHODS}

Animals: A total of fifteen regular 4-day cycling female rats of Sprague-Dawley strain weighing between 120-180 g, procured from the Nigerian Institute of Medical Research (NIMR) Yaba, Lagos, Nigeria were used for this study. The animals were housed in the department of Anatomy, Faculty of Basic Medical Sciences, College of Medicine, University of Lagos. They had access to food and water ad libitum. They were maintained at $25 \pm 3^{\circ} \mathrm{C}$ with photoperiodicity of 12: 12 light:darkness. The animals were weighed and randomly divided into 5 per cage. All animals were observed for clinical signs of drug toxicity throughout the duration of the experiment. Experiments were carried out in accordance with the guidelines of the committee on use of laboratory animals and the departmental ethical committee.

Amodiaquine: Pure $\mathrm{AQ} . \mathrm{HCl}$ a product of Rhone Poulenc ${ }^{\mathrm{TM}}$ France was constituted into a solution by the addition of distilled water. We chose to administer $\mathrm{AQ}$ at the doses of $6 \mathrm{mg}$ and12 $\mathrm{mg} / \mathrm{kg}$ bw based on the body weight of the rats by extrapolating from the recommended therapeutic human dose. AQ was administered orally by gavage.

Determination of the oestrous cycle: Oestrous cyclicity was determined between 8 a.m. and 10a.m. using the vaginal smear method. Vaginal secretion was collected with a plastic pipette filled with $10 \mu \mathrm{L}$ of normal saline $(\mathrm{NaCl} 0.9 \%)$. The vagina was flushed two or three times with the pipette and the vaginal fluid was placed on a glass slide. A different slide was used for each animal. The unstained secretion was observed under a light microscope.

After confirming regular 4-day cyclicity for 2 weeks, the animals were selected for this study. The effect of AQ. $\mathrm{HCl}$ on the oestrous cycle was monitored for 28days (Gasco et al., 2008).

Tissue processing for light microscopy: At the end of the $28^{\text {th }}$ day treatment period, the animals were sacrificed by cervical dislocation. The ovaries were accessed and removed following a ventral laparectomy, trimmed of fat and fixed in $10 \%$ formol saline. The fixed tissues were dehydrated in increasing concentrations of ethanol and thereafter embedded in paraffin wax. Serial sections of $7 \mu \mathrm{m}$ thick were made. These were stained with haematoxylin and eosin in the routine H\&E preparation.

Preparation of tissues for biochemical analysis: The ovarian tissues were kept frozen at $-80^{\circ} \mathrm{C}$ until the day of assay. The tissues were homogenized in saline $(1: 10, w / v)$ on ice, and the homogenates were centrifuged at $10,000 \mathrm{~g}$ for $15 \mathrm{~min}$ at $4{ }^{\circ} \mathrm{C}$. After centrifugation, the clear supernatants were removed and used for CAT and SOD activities.

Tissue SOD activity: SOD was assayed using a modification of the technique of Kakkar et al., (1984). A single unit of enzyme was expressed as $50 \%$ inhibition of Nitroblue tetrazolium (NBT) reduction $/ \mathrm{min} / \mathrm{mg} /$ protein.

Tissue CAT activity: CAT was assayed colorimetrically at $620 \mathrm{~nm}$ and expressed as $\mu$ moles of $\mathrm{H}_{2} \mathrm{O}_{2}$ Consumed $/ \mathrm{min} / \mathrm{mg} /$ protein as described by Sinha (1972). The reaction mixture $1.5 \mathrm{ml}$ contained $1.0 \mathrm{ml}$ of $0.01 \mathrm{M} \mathrm{pH} 7.0$ phosphate buffer, $0.1 \mathrm{ml}$ of ovary homogenate and $0.4 \mathrm{ml}$ of $2 \mathrm{M} \mathrm{H}_{2} \mathrm{O}_{2}$. The reaction was stopped by the addition of $2.0 \mathrm{ml}$ of dichromate-acetic acid reagent $5 \%$ potassium dichromate and glacial acetic acid was mixed in 1:3 ratios.

Statistical analysis: Results were expressed as mean \pm standard deviation (Mean \pm SD) and subjected to statistical analysis using analysis of variance (ANOVA) followed by Bonferroni's post-hoc test. Statistical significance was considered at $p<$ 0.05 or $5 \%$.

\section{RESULTS}

The result displayed in table 1 showed that the mean cycle length of the oestrous cycle was prolonged in the groups that received $\mathrm{AQ} . \mathrm{HCl}$ at $6 \mathrm{mg}$ and 12 $\mathrm{mg} / \mathrm{kg}$ bw when compared with the control. This increase in mean cycle length was statistically significant $(p<0.05)$ at both doses. 
Table 1: The effect of the administration of AQ for 28 days on the length of the oestrous cycle in Sprague-Dawley rats

\begin{tabular}{|lc|}
\hline Treatment groups & Length of oestrous cycle (Mean \pm SD) \\
\hline control & $4.00 \pm 0.00$ \\
$6 \mathrm{mg} / \mathrm{kg} \mathrm{bw}$ & $5.04 \pm 0.43^{*}$ \\
$12 \mathrm{mg} / \mathrm{kg} \mathrm{bw}$ & $6.06 \pm 1.63^{*}$ \\
\hline${ }^{*}=p<0.05$ & \\
\hline
\end{tabular}

Table 2 shows a statistically significant increase $(p<$ 0.05 ) in the number of days the animals spent in the diestrus phase in the AQ-treated groups in comparison with the number of days spent in the metestrus, proestrus, and estrus phases when compared with the control group. Histological sections of the ovaries in the control group show a single, focal pseudostratified layer of modified peritoneal cells. The cells varied from flat to cuboidal and columnar types. Cortical and medullary stroma was continuous, and the boundary between these two zones was ill-defined and arbitrary (Plates 1A \& 1B). Ovarian follicles of various sizes with well defined theca interna and theca externa were observed. Each follicle contains a single oocyte in the stroma of the cortex. The oocyte within the graffian follicle is enveloped by the zona pellucida (ZP) and guarded by the granulosa cells. Few corpora lutea were observed in the cortex. Stromal cells immediately surrounding the follicle formed a sheath of connective tissue. Vessels penetrated into the cortex through the stroma.

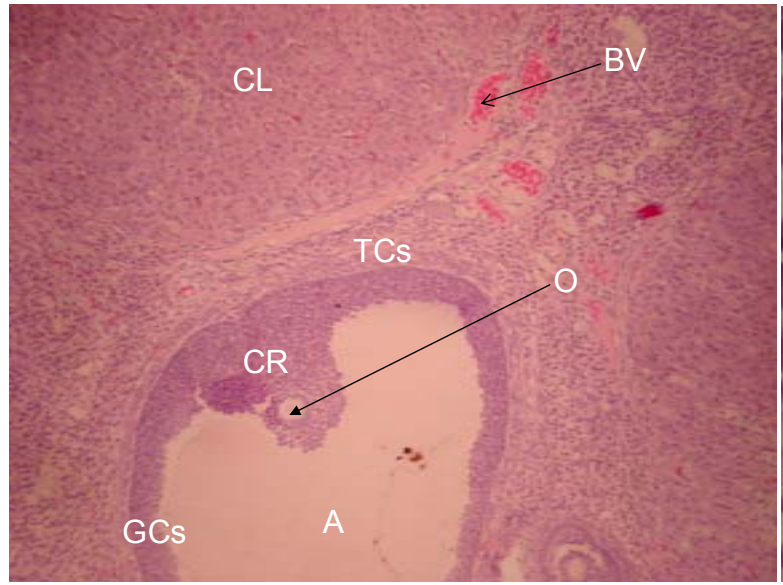

Plate 1A (x100)

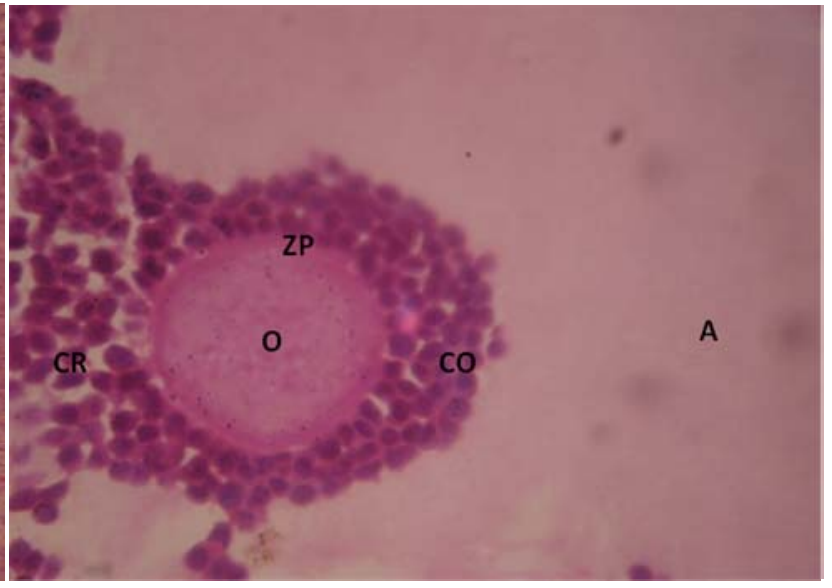

Plate 1B (x400)

Plate 1A and 1B: Micrograph of cross-section of ovary of rat in control group showing a normal ovary demonstrating blood vessel (BV), corpus luteum (CL) and a matured graafian follicle is seen showing oocyte (O), corona radiata (CR), zona pellucida (ZP) granulosa cells (GCs) antrum (A) and well defined theca cells (TCs). 
Agric. Biol. J. N. Am., 2011, 2(4): 630-637

Table 2: The effect of the administration of amodiaquine on the phases of the oestrous cycle in Sprague-Dawley rats.

\begin{tabular}{|lllcl|}
\hline Treatment groups & Metestrus & $\begin{array}{l}\text { Diestrus } \\
(\% \text { number of days })\end{array}$ & Estrus \\
\hline Control & 25.00 & 25.00 & 25.00 & 25.00 \\
\hline $6 \mathrm{mg} / \mathrm{kg}$ & 19.86 & $39.07^{*}$ & 19.21 & 21.85 \\
\hline $12 \mathrm{mg} / \mathrm{kg}$ & 18.26 & $46.09^{*}$ & 18.26 & 17.39 \\
\hline
\end{tabular}

$x=p<0.05$

The ovarian sections of the rats administered 6 $\mathrm{mg} / \mathrm{kg}$ bw $\mathrm{AQ} . \mathrm{HCl}$ alone orally for 28 days when compared to the control showed increased number of atretic follicles characterized by degenerated oocytes

and zona pellucida, disintegrated granulosa cell layers and also a distortion/destruction of the basement membrane separating the theca cells from the granulosa cell layers (Plates 2A \& 2B)

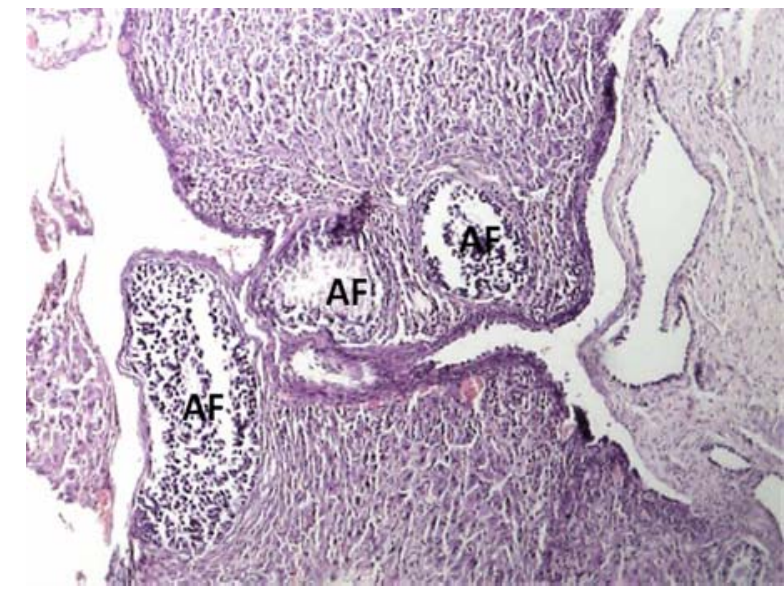

Plate 2A (x100)

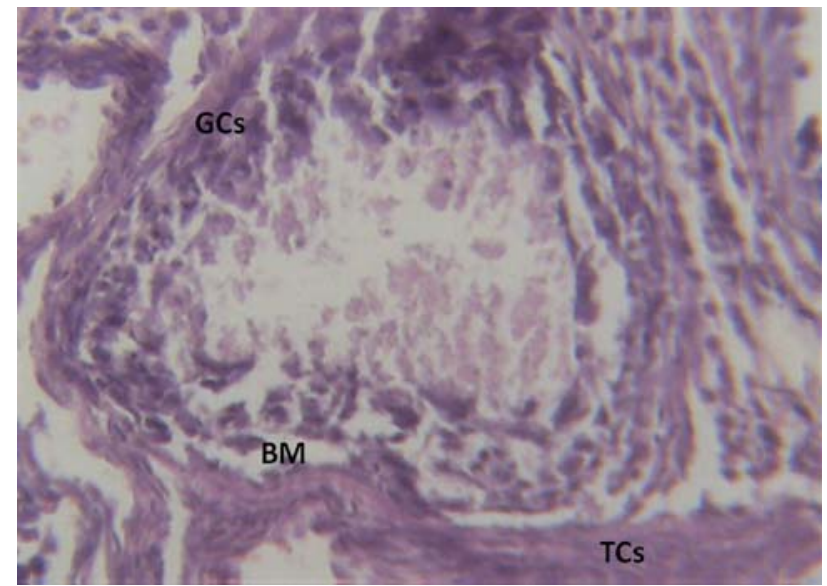

Plate 2B (x400)

Plates 2A and 2B: Micrograph of cross-section of ovary of rat treated with $6 \mathrm{mg} / \mathrm{kg}$ bw of AQ for 28 days showing atretic follicles characterized by degenerated oocytes and zona pellucida, disintegrating granulosa cells (GCs) and a destruction of the basement membrane separating the granulosa cell layer from the theca cells (TCs).

At $12 \mathrm{mg} / \mathrm{kg}$ bw $\mathrm{AQ} . \mathrm{HCl}$ oral route, histological sections showed numerous atretic follicles about 6 per profile characterized by degenerated oocytes, degenerated zona pellucida, disintegrated granulosa cell layers and also a distortion/destruction of the basement membrane separating the theca cells from the granulosa cell layers when compared with the control rat ovary (Plates $3 A \& 3 B$ ). 


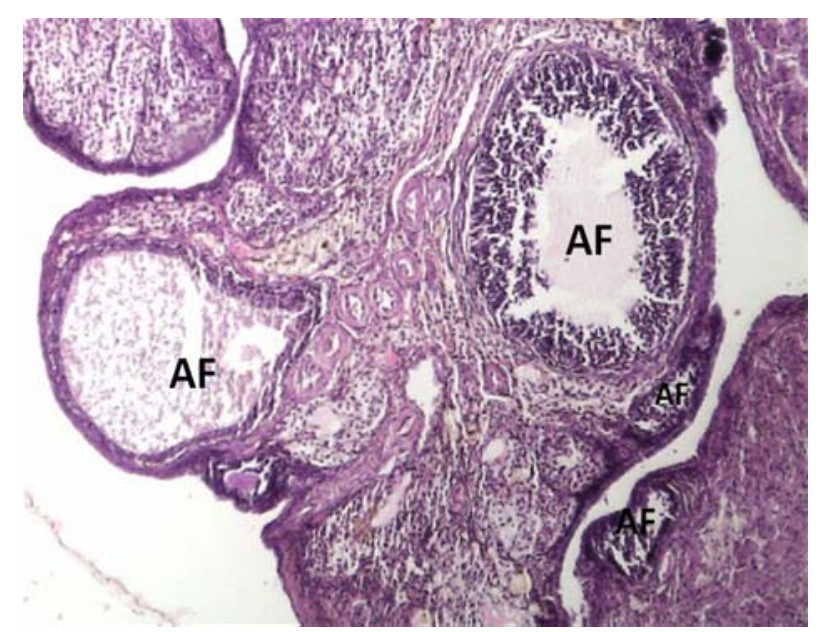

Plate 3A (x100)

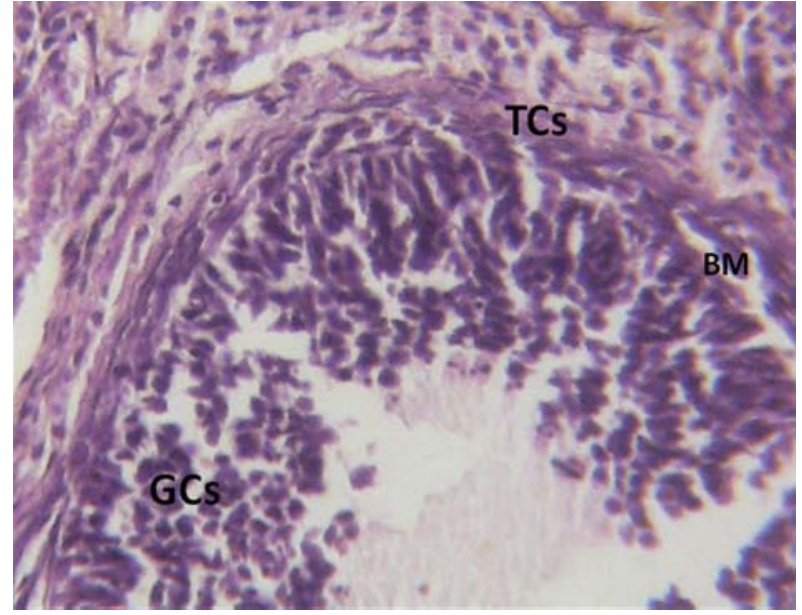

Plate 3B (x400)

Plates 3A and 3B: Micrograph of cross-section of ovary of rat treated with $12 \mathrm{mg} / \mathrm{kg}$ bw of AQ for 28 days showing numerous atretic follicles characterized by degenerated oocytes and zona pellucida, disintegrating granulosa cells (GCs) and a destruction of the basement membrane separating the granulosa cell layer from the theca cells (TCs).

Effect of $A Q$ on SOD and CAT activities in the ovary: The result obtained from this study revealed that the administration of $\mathrm{AQ} . \mathrm{HCl}$ at $6 \mathrm{mg} / \mathrm{kg}$ bw and $12 \mathrm{mg} / \mathrm{k} \mathrm{g}$ bw doses caused a reduction in the activities of SOD and CAT in the ovary of SpragueDawley rats when compared to the control. The reduction in the activity of CAT was statistically significant $(p<0.05)$ at both doses (Table 3$)$.

Table 3: The effect of the administration of $A Q$ for 28 days on enzymatic anti-oxidants activities of catalase (CAT) and superoxide dismutase (SOD) in the ovary of Sprague-Dawley (S-D) rats.

\begin{tabular}{|l|l|l|}
\hline Treatment groups & Anti-oxidant activities of CAT and SOD in the ovary of S-D rats \\
\hline & CAT $(\mathrm{Mmol} / \mathrm{min} / \mathrm{mg}$ protein) & SOD (min/mg protein) \\
\hline Control & $84.8 \pm 49.1$ & $.40 \pm 0.85$ \\
\hline $6 \mathrm{mg} / \mathrm{kg}$ & $55.5 \pm 26.5^{\star}$ & $0.96 \pm 0.71$ \\
\hline $12 \mathrm{mg} / \mathrm{kg}$ & $46.5 \pm 26.5^{\star}$ & $1.09 \pm 0.63$ \\
\hline
\end{tabular}

$\mathrm{x}=\mathrm{p}<0.05$

\section{DISCUSSION}

Rats typically have rapid cycle times of 4 to 5 days and the events of the cycle are strongly influenced by photo-periodicity (Freeman, 1994).

Compared to the control, the length of the oestrous cycle increased significantly $(p<0.05)$ in the AQtreated groups. Nevertheless, the mean cycle length of 5.04 days recorded in the group that received 6 $\mathrm{mg} / \mathrm{kg}$ bw of $A Q . \mathrm{HCl}$ is in concert with the study of Long and Evans (1922), Astwood (1939) and Blandau et al. (1941) who recorded a mean cycle length of $5.4,4.5$ and 4.4 days respectively. The group that received the high dose $(12 \mathrm{mg} / \mathrm{kg}$ bw of $\mathrm{AQ} . \mathrm{HCl}$ ) recorded a mean cycle length of 6.06 days demonstrating that the animals had a longer mean cycle length at $12 \mathrm{mg} / \mathrm{k} \mathrm{g}$ bw than at $6 \mathrm{mg} / \mathrm{kg}$ bw.
However this difference in mean cycle length experienced in the two dosage treatments was not statistically significant. The effect of $A Q . \mathrm{HCl}$ on the length of the oestrous cycle observed in this study occurred as a result of the animals spending longer days in the diestrus phase (prolonged diestrus phase). The result of this study is in concert with the findings of Okanlawon and Ashiru (1992). In their study to determine the effects of chloroquine (CQ) on the oestrus cycle in 4-day cyclic Sprague-Dawley rats, the authors administered $40 \mathrm{mg} / \mathrm{kg}$ bw CQ phosphate intraperitoneally once a day five days in a week. The result of their study demonstrated that the administration of $\mathrm{CQ}$ altered the oestrus cycle through a persistent diestrus smear. The similarity in our findings may possibly be due to the similarity in the structure of chloroquine and $A Q$. 
It has been reported previously that progesterone secretion remains higher during diestrus in the 5-day cyclic rat than in the 4-day (Nequin et al., 1979). These researchers suggest that the 5 -day cycle is due to the prolonged progesterone secretion from a new crop of corpora lutea during diestrus. The LHindependent luteal secretion of progesterone during diestrus phase begins to rise in the afternoon of metestrus, reaches peak values by early morning of diestrus, and falls to basal levels shortly thereafter (Smith et al., 1975). It is well established that the progesterone secreted during diestrus intensifies the negative feedback of estradiol on basal LH secretion and that when these levels of progesterone fall at luteal regression, the secretion of estradiol and $\mathrm{LH}$ rises and ovulation occurs within the following 6- $8 \mathrm{~h}$ (Beattie and Corbin, 1975; Smith et al., 1975; Taya et al., 1981; Kaneko et al., 1986). Therefore the action of gonadotropins on estrogens secretion is not a process triggered immediately in an all-or-none fashion. Instead, gonadotropins must continue to act for some time for ovarian estrogen secretion to increase. The prolongation of luteal progesterone secretion in an oestrous cycle suppresses pituitary gonadotropin secretion. Rather than blocking the estrogen triggering of ovulatory LH surge, directly, it delays the estrogen secretion itself, which decreases the threshold of the neural and/or hypophyseal structures for ovulatory LH release. In this study progesterone level was not determined so it cannot be substantiated at this stage whether the persistent diestrus observed in this study was as a result of prolonged progesterone levels.

The sections demonstrated ovarian follicles in various stages of development with normal appearance in the ovarian cortex. A follicle is considered to be undergoing atresia/regression whenever the following structural changes occur: two or more pyknotic granulosa cells are found in a single section, hypertrophy of theca cells, denuded oocyte and zona pellucida or thinning of cumulus oophorus and destruction of basal lamina (Osman, 1985; Azarnia et al., 2004; Koc et al., 2009). The histopathological examination of ovaries of animals treated with AQ. $\mathrm{HCl}$ for 28 days revealed that the most remarkable change was widespread ovarian follicle atresia in comparison to the control group. The atretic follicles were characterized by degenerated oocytes and zona pellucida, disintegrated granulosa cells and a distortion/destruction of the basement membrane separating the theca cells from the granulosa cell layer (Osman, 1985; Azarnia et al., 2004; Koc et al., 2009). The result of this study is in concert with previous investigators who reported increase in the number of atretic follicles when Lead and Artemesia annua was administered to mouse and rat ovaries respectively (Roth and Hansen, 2004; Jancar et al., 2007; Ajah and Eteng, 2010). This study suggests that $A Q$ may have inhibited the maturation process of the follicles.

Granulosa cells are essential in the normal follicular maturation process since they produce steroidal hormones and growth factors and also they play a crucial role in follicular atresia. Apoptosis of granolusa cells seems to have a negative effect on follicular maturation. A higher incidence of apoptotic granulosa cell has been associated with fewer oocytes retrieved and poorer quality of oocytes and embryos (Jancar et al., 2007).

Various pathological stimuli such as oxidative stress (OS) can initiate apoptosis in mammalian oocytes (Roth and Hansen, 2004). Intra-cellular accumulation of reactive oxygen species (ROS), can damage cells by causing nucleic acid strand breaks, lipid peroxidation, protein degradation and ultimately, cell death (Yu, 1994). It has been suggested that steroidogenically active cells such as granulosa cells of antral follicles, require high levels of energy production and thus generate large amounts of ROS (Rapoport et al., 1999). Therefore it is possible that OS is involved in the mechanisms that trigger apoptosis in healthy steroidogenic antral follicles (Jancar et al., 2007).

Some evidence based histopathological changes of oxidative stress have been observed and characterized in the ovary. They include vascular congestion, atretic follicles, haemorrhage, edema and inflammatory cells infiltration (Coskun, et al., 2007; Guven et al., 2008; Halici et al., 2008). In this study, although not all the classical features of oxidativestress induced histopathological changes were observed however, it cannot be completely excluded that the ovary may be under some form of oxidative stress. Therefore, it can be deduced from this study that chronic administration of $\mathrm{AQ} . \mathrm{HCl}$ produces deleterious effect in the ovary by increasing follicular atresia.

All forms of aerobic life face the threat of oxidation from molecular oxygen $\left(\mathrm{O}_{2}\right)$. Conceivably to cope with various ROS, different classes of enzymatic and nonenzymatic antioxidants have evolved. Antioxidants function by preventing the accumulation of toxic levels of oxygen-derived free radicals, which can damage the cells by modifying proteins, lipids, 
and DNA. An imbalance between free radical prooxidants and anti-oxidants has important implications for both physiological and pathological processes in the reproductive tract (Agarwal et al., 2005). The enzyme SOD catalyses dismutation of superoxide radical, leading to formation of hydrogen peroxide, which in turn is detoxified by the enzyme catalase (Rzeuski et al., 1998). In this study we observed a decrease in the anti-oxidant status of SOD and CAT in all the AQ-treated animals. This decrease was statistically significant $(p<0.05)$ for CAT activities. The decreased activities of SOD and CAT in our study are concomitant with the studies of Das et al. (2001) and Rao et al. (2009) who have documented reduced activity of these enzymes in the hepatic tissue and in the mouse ovary respectively, in support of our results. Therefore a reduction in cellular enzymatic activities of SOD and CAT is clearly indicative of oxidative stress.

\section{CONCLUSION}

The result of this study demonstrates that $A Q . H C l$ causes increased production of reactive oxygen species and consequently leads to a state of oxidative stress in the ovary. This is expressed histologically by widespread increase in follicular atresia, and biochemically by reduction in enzymatic anti-oxidant status of SOD and CAT in the ovary.

\section{REFERENCES}

Agarwal, A., Gupta, S. and Sharma, R.K. (2005): Role of oxidative stress in female reproduction. Reprod. Biol. Endocrinol. 3: 28

Ajah, P.O. and Eteng, M.U. (2010): Phytochemical screening and histopathological effects of single acute dose administration of Artemisia annua L. on testes and ovaries of Wistar rats. Afr. J.Biochem.Res. 4: 179-185.

Anon, (1990): Practical chemotherapy of malaria. Report of a WHO Scientific Group. World Health Organ. Tech. Rep. Ser. 805:1-141.

Astwood, E. B. (1939): Changes in the weight and water content of the uterus of the normal adult rat. Am. J. Physiol. 126: 162-70.

Azarnia, M., Shakour A., Rostami, P. and Sanaie-Mehr A. (2004): the protective role of l-cysteine against follicular atresia induced by lead in mouse ovary. Acta Medica Iranica, 42: 83-88.

Beattie, C.W. and Corbin, A. (1975): The differential effects of diestrous progesterone administration on proestrous gonadotropin levels. Endocrinol. 97: 885-980.

Bepler, C.R., Baier, H.N., McCracken, S., Rentschler, C.L., Rogers, F.B. and Lansbury, J. (1959): A 15 month controlled study of the effects of amodiaquine (camoquin) in rheumatoid arthritis. Arth. Rheum. 2: 403-413.

Blandau, R.J., Boiling, J.L. and Young, W.C. (1941): The length of heat in the albino rat as determined by the copulatory response. Anat. Rec. 79: 453-463.

Brasseur, P., Guiguemde, R., Diallo, S., Guiyedi, V., Kombila, M., Ringwald, P. et al., (1999): Amodiaquine remains effective for treating uncomplicated malaria in west and central Africa. Trans. R. Soc. Trop. Med. Hyg. 93: 645-650.

Coskun, A., Coban, Y. K. and Ciralik, H. (2007): Critical ischemic time for the rat ovary: Experimental study evaluating early histopathologic changes. J. Obst. Gynaecol. 35: 330-334.

Das, K.K., Das, S.N. and DasGupta, S. (2001): The influence of nickel induced hepatic lipid peroxidation on rats. J. Basic Clin. Phy. Pharm. 12: 187-195.

Freeman, M.E. (1994): The neuroendocrine control of the ovarian cycle of the rat. In: Knobil, E., Neill, J.D., Greenwald, G.S., Clement, L.M. and Donald W.P. (eds.), The Physiology of Reproduction, vol. 2, $2^{\text {nd }}$ ed. New York: Raven Press pp 613-658.

Gasco, M., Yucra, S., Rubio, J. and Gonzalez, G.F. (2008): Lepidium meyenii (Maca) varieties did not alter female reproductive parameters in adult intact rats. J. Compl. Integ. Med. 5: A15.

Guven, S., Muci, E., Unsal, M.A., Yulug, E., Alver, A., Duman, M.K. et al., (2010): The effects of carbon dioxide pneumoperitoneum on ovarian blood flow, oxidative stress markers, and morphology during laparoscopy: a rabbit model. J. fertile. Steril. 93: 1327-1332.

Halici, Z., Karaca, M., Keles, O.N., Borekci, B., Odabasoglu, F., Suleyman, H. et al., (2008): Protective effects of amlodipine on ischemiareperfusion. Injury of rat ovary: biochemical and histopathologic evaluation. J. Fertil. Steril. 90: 2408-2415.

Jancar, N., Kopitar, A.N., Ihan, A., Virant Klun, I and Bokal, E.V (2007): Effect of apoptosis and reactive oxygen species production in human granolusa cells on oocyte fertilization and blastocyst development. J. Assist Reprod. Genet. 24: 91-7.

Kakkar, P., Dos, B. and Viswnathan, P.N. (1984): A modified spectrophotometric assay of superoxide dismutase. Indian J. Biochem. 21: 130-132.

Kaneko, S., Sato, N., Sato, K. and Hashimoto, I. (1986): Changes in plasma progesterone, estradiol, folliclestimulating hormone and luteinizing hormone during diestrus and ovulation in rats with 5-day estrous cycles; effect of antibody against progesterone. Biol Reprod. 34: 488-494.

Koc, N.D., Kayhan, F.E., Sesal, C. and Muslu, M.N. (2009): Dose-dependent effects of endosulfan and malathion 
on adult wistar albino rat ovaries. Pak. J. Biol. Sci. 12: 498-503.

Kone, B., Ouedraogo, C. and Guiguemde, T.R. (2002): Affections tropicales et grossesse. Traite d'Obstetrique. 141: 5-043 A-40.

Long, J. A. Evans, H. M. (1922): The estrous cycle of the rat and its associated phenomena. Mem. Uni. Calif. 6: $1-148$.

Markham, L.N., Giostra, E., Hadengue, A., Rossier, M., Rebsamen, M., Desmeules, J. (2007): Emergency liver transplantation in amodiaquine-induced fulminant hepatitis. Am. J. Trop. Med. Hyg. 77: 14-15.

Minzi, O.M., Moshi, M.J., Hipolite, D., Massele, A.Y., Tomson, G., Ericsson, O. et al. (2003): Evaluation of the quality of amodiaquine and sulphadoxine/pyrimethemine tablets sold by private wholesale pharmacies in Dar Es Salaam, Tanzania. J. Clin. Pharm. Ther. 28: 117-122.

Misra, S.P., Nandi, J and Lai, S. (1995): Chloroquine versus amodiaquine in the treatment of plasmodium falciparum malaria in northeast India. Indian J. Med. Res. 102: 119-123.

Neftel, K.A., Woodtly, W., Schmid, M., Frick, P.G. and Fehr, J. (1986): Amodiaquine induced agranulocytosis and liver disease. Br. Med. J. 292: 721-723.

Nequin, L.G., Alvarez, J. and Schwartz, N.B. (1979): Measurement of serum steroid and gonadotropin levels and uterine and ovarian variables throughout the 4-day and 5-day estrous cycles in the rat. Biol. Reprod. 20: 659-670.

Ngouesse, B., Basco, L.K., Ringwald, P., Keundjian, K. and Blackett, K.N. (2001): Cardiac effects of amodiaquine and sulphadoxine-pyrimethamine in malaria-infected African patients. Am. J. Trop. Med. Hyg. 65: 711-716.

Okanlawon, A.O. and Ashiru, O.A. (1992): Effect of chloroquine on estrus cycle and ovulation in cyclic rats. J. Appl. Toxicol. 12: 45-48.

Olliaro, P. and Taylor, WRJ. (2004): Amodiaquine for the treatment of uncomplicated falciparum malaria. $\mathrm{J}$. Postgrad. Med. 50: 40-44.

Olliaro, P., Nevill, C., LeBras, J Ringwald P, Mussano P, Garner P. et al. (1996): Systematic review of amodiaquine treatment in uncomplicated malaria. Lancet. 348: 1196-1201.

Osman, P. (1985): Rate and course of atresia during follicular development in the adult cycle rat. J. Reprod. Fertil. 73: 261-270.

Perret, J.L. and Ngomo, M.J. (1993): Antimalarial selfmedication in adults consulting for fever at the hospital centre of Libreville, Mèdecine d'Afrique Noire. 40: 522-524.
Pomeroy, H., Warren, C., Mills, D. and Clark, G.M. (1959): The effect of amodiaquine (camoquin) on the course of rheumatoid arthritis. Arthr. Rheum 2: 396-402.

Rao, M.V., Chawla, S.L. and Sharma, S.R. (2009): Protective role of vitamin $\mathrm{E}$ on nickel and/or chromium induced oxidative stress in the mouse ovary. Food Chem. Toxicol, 47: 1368-1371.

Rapoport, R., Shlan, D. and Hanukoglu, I. (1999): Electron leakage from the adrenal cortex mito chondrial P450 scc and P450 cll systems: NADPH and steroid dependence. Arch. Biochem biophy. 5617: 412-416.

Roth, Z. and Hansen, P.J. (2004): Involvment of apoptosis in distruption of developmental competence of bovine oocytes by heat shock during maturation. Biol. Reprod. 71: 1898-1906.

Rzeuski, R., Chlubek, D. and Machoy, Z. (1998): Interactions between fluoride and biological free radical reactions. Fluoride 31: 43-45.

Schellenberg, D. and Menendez, C. (2001): Intermittent treatment for malaria and anaemia control at time of routine vaccinations in Tanzanian infants: a randomised, placebo controlled trial. Lancet. 357: 1471-1477.

Sinha, A.K. (1972): Colorimetric assay of catalase. Anal. Biochem. 47: 389-394.

Smith, M.S., Freeman, M.E. and Neill, J.D. (1975): The control of progesterone secretion during the estrous cycle and early pseudopregnancy in the rat: prolactin, gonadotropin and steroid levels associated with rescue of the corpus luteum of pseudopregnancy. Endocrinol. 96: 219-226.

Steketee, R.W., Brandling-Bennett, A.D., Kaseje, D.C., Schwartz, IK and Churchill, F.C. (1987): In vivo response of plasmodium falciparum to chloroquine in pregnant and non-pregnant women in Siaya District, Kenya. Bull World Health Organ. 65: 885-890.

Taya, K., Terranova, P.F. and Greenwald, G.S. (1981): Acute effects of exogenous progesterone on follicular steroidogenesis in the cyclic rats. Endocrinol. 108: 2324-233.

Thomas, F., Erhart, A., D'Alessandro, U. (2004): Can amodiaquine be used safely during pregnancy? Lancet Infect Dis. 4: 235-239.

World Health Organization, (2001): Antimalarial drug combination therapy: Report of World Health Organization technical consultation. Geneva.

Yu, B.P. (1994): Cellular defences against damage from reactive oxygen species. Physiol. Rev. 74: 139-62. 